\title{
The Humanity of Children from Sandmann to Struwwelpeter: A Tale of Two Hoffmanns Gail Hart \\ University of California, Irvine
}

Within the context of an inquiry into the borders between human and animal, this essay considers the question of the humanity--or animality--of children as they are depicted in nineteenth-century German literature and elsewhere. Defining nineteenth-century literary "humanity" as a regulating, domesticating, bourgeoisification, I examine E.T.A. Hoffmann's Der Sandmann and Heinrich Hoffmann's Der Struwwelpeter, and follow the sins of omission (Sandmann) and commission (Struwwelpeter) that seem to authorize the inhuman treatment of children. Nathanael, Coppelius's "little beast," is reduced both to beast and automaton/wooden doll and ultimately destroyed in E.T.A. Hoffmann's adult novella. Twenty-nine years later, the young protagonists of Heinrich Hoffmann's children's book suffer gruesome punishments for their willful transgression of bourgeois norms and domestic law. But the children's rhymes produced in 1845 have a revolutionary flavor that underscores the subject's freedom.

Gail K. Hart is Professor of German at the University of California, Irvine and recently served as Chair of the Department of European Languages and Studies, Director of the Campuswide Honors Program (2009-2012), and Director of Humanities Core Course (2000-2007). She had also served as Associate Dean of Humanities, Director of the University of California's Education Abroad Programs in Germany, Director of International Education (2000-03), and President of the Pacific Ancient and Modern Language Society. Her research concerns 18th and 19th-century German literature and culture with a focus on Schiller's aesthetics and nineteenth-century prose fiction. She is the author of three books and numerous articles and is currently working on a larger project on the meaning of "freedom" in German culture and history 1785-1871 and a smaller project on non-sports bubble gum trading cards in the US in the 1930s.

Defining the human and the animal can also take the form of defining the human - or pre-human - as animal and the consequences of this shift in perspective or effacement of borders are the subject of this essay that follows the affinities of children with animals and other forms of non-humanity. Are children human? Or more like animals? Is there any exalted concept of 'humanity' beyond the biological that we can stretch to encompass children, those instinctual beings who are neither socialized nor civilized? Our long and tortured debate over abortion centers on the question, When does life begin? Does it begin at conception or quickening or birth? I want to modify the question slightly to 
address the qualities of being human (whatever they are): When does humanity begin? Or, more specifically for my purposes, when does bourgeois humanity, with all of its entitlements to respectful and civilized treatment, begin? Not at birth, to be sure, but at some point during the socialization and civilization process, when the bourgeois citizen-in-training achieves a certain adequate level of adherence to norms as perceived by those doing the training. I am deliberately aligning "humanity" with a regulating, domesticating bourgeoisification here in order to reflect common literary perspectives of nineteenth-century Germany, where housebroken children, whose animal nature has been sufficiently suppressed, can join the cultural conversation while their less well-trained coevals remain in the nursery - where terrible things can happen.

This is something of a generalization and there are certainly exceptions, but I believe that when we see children in nineteenth-century German literature, they are presented as positive or negative examples of acquired humanity. Either they internalize the normative regimen or they remain abjected pre-humans. There is little middle ground or ambivalence, like that expressed in the early twentieth century by Kafka's ape, Rotpeter, who sees his acquisition of humanity-humanity being a capacity for speech and an apprehension of bourgeois values-as being merely an accommodation to difficult circumstances. In the nineteenth century, it is simply good to be human--here meaning civilized according to western, middle-class norms-- and, Mignon aside, bad not to be. There are of course hiccups on the training course and those trainees who aspire to humanity experience setbacks as well as victories. This essay follows hiccups described by Hoffmanns, specifically the trauma repetition of a stalled childhood in E.T.A. Hoffmann's Der Sandmann (1816) and the lessons not learned in Heinrich Hoffmann's Der Struwwelpeter (1845). In both cases, the subjects will a course of action or inaction that runs counter to civilization and we witness the pain and terror of pre-human existence in civilization's retribution.

Both texts are still widely read today. Freud immortalized Sandmann when he examined it in his essay on das Unheimliche or the uncanny (Freud 1919) and because of, in spite of, or independent of that, it was and remains one of 
Hoffmann's most popular tales. Offenbach's opera, dating from the 1850 s, featured the tale with Hoffmann himself as the hero smitten by the automaton Olimpia; the tales and the tale form the basis of four or five of the earliest European films, and the excellent 1951 Michael Powell/Emeric Pressburger film of the opera/ballet features the dismemberment of Moira Shearer, playing the wooden doll. Something about this tale that repeatedly opposes and combines the human and the automaton, as well as the animal - ultimately questioning the distinctions - has taken root in our cultural imagination. And regarding cultural imagination, the fears that Sandmann evokes, the terror of being de-humanized and subordinated to the will of an evil manipulator, strongly resemble those of Caribbean zombie culture, which feeds our current dalliance with zombies. In Haiti and elsewhere in the Caribbean, believers did not fear being attacked by zombies, but rather becoming zombies as a result of manipulation by voodoo priests. Elaborate burial practices intended to prevent disinterment and reanimation attest to this fear. But while zombies and automatons belong to the realm of the post-human, children are the pre-human, similarly excluded from full humanity but still (like zombies and automatons) uncannily similar to members of that group called 'us.'

Heinrich Hoffmann's much shorter tales are probably even better known than Der Sandmann, because they were read by generations of pre-humans who tend to recall them with horror, professing a kind of Post-Struwwelpeter Stress Disorder into adulthood. The unshorn, long-nailed image of the titular figure is a cultural icon, technically reproduced for a wide variety of purposes, especially political parody as there are Struwwel-Hitlers, Struwel-Gerhard Schroeders, and Struwel-Nixons. ${ }^{1}$ What these two texts, Sandmann and Struwwelpeter, have in common is an emphasis on the violent operations that can legitimately be performed on those who have not yet crossed the border that separates a childhood dominated by instinct and a civilized or socialized maturity. What would otherwise be obvious transgressions against these children are justified or rationalized by the fact that the victims are not yet fully human and that the abuse will assist the child in learning the ways of the world. These two texts, which here 
stand in for German literature in the first half of the nineteenth century, are twenty-nine years apart and of different genres; one is a novella for adults and the other a child's verse and picture book. But they both consider and confirm the basic assumption that children are a species of non-humans, creatures who need not be treated according to the norms of human decency. The violation of these norms is often extreme and it occurs, interestingly, without the pathos associated with cruelty to animals. Nasty little Frederick, for example, de-wings a fly and beats his dog and we are invited to disapprove, but we are guided toward selfsatisfied affirmation when the dog bites him. In Struwwelpeter, the violent consequences of misbehavior often occur in the presence of domesticated animals who are themselves well-behaved. They seem to be a step ahead of the children in the matter of humanlike-ness and their enlightened deportment exempts them from the approved abuse reserved for the children. In the case of Paulinchen, one of the two protagonists whose misbehavior has fatal consequences, it is the cats, Minz and Maunz, who try to dissuade her from playing with matches. At the end, their tears dampen the fire that has already consumed her. Had she only listened to them! $!^{2}$ Here, the domesticated animal, by virtue of its domestication, ranks above the child on the scale of bourgeois behavior, suggesting, oddly, that deportment and not physiology may define the animal and the human.

\section{Der Sandmann}

Ernst Theodor Amadeus Hoffmann was, in addition to being a major German Romantic writer, also a musician, composer, music teacher, music critic, caricaturist, and Prussian bureaucrat. Moving among capitals and backwaters, he encountered many of the movement's major figures but despite these connections he retained a uniquely cynical style, portraying for example a number of clueless and untalented artists within a movement that tended to glorify artistic creation as the highest human achievement. Der Sandmann, written in 1816, appeared in 1817 in the collection Nachtstücke or 'Night Pieces.'

Nathanael, who is Hoffmann's protagonist in Sandmann and another of his bad poets, spends his childhood in a home regularly disrupted by the frightening 
lawyer Coppelius, a frequent dinner guest whom the child associates with the dreaded Sandman. The latter, protagonist of a common children's myth, admits of milder descriptions, but Nathanael strongly prefers his old nurse's version:

An evil man who comes to children when they don't want to go to bed and throws handfuls of sand into their eyes, so that, all bloody, the eyes pop out of their heads. Then he throws the eyes in a sack and carries them to the half-moon to feed his children. They sit up there in a nest and have crooked beaks like owls with which they peck at the bad children's eyes. (Hoffmann 13) ${ }^{3}$

It is of note that Nathanael's Sandman is a human being ("evil man") whose offspring are birds - an observation that literalizes the animal character of children in contrast to the human nature of adults. Accordingly, Nathanael notes that Coppelius always referred to him and his siblings as "the little beasts" ("kleine Bestien," Hoffmann 16), relegating them to the realm of the non-human. As dinner guest, Coppelius purposely spoils the children's enjoyment of the small treats Nathanael's mother serves them, touching them with his big hairy fingers a contamination that disgusts the children. His effect on the parents is equally pernicious: Nathanael's mother grows sad when a visit from Coppelius is expected and his father becomes distracted and has no time for the children. There is the definite suggestion that Coppelius represents the father's erotic aspect, his animal nature that overcomes his interest in the children and causes him to sequester himself, while oppressing his wife. His association with eyes, which Freud, citing Oedipus, sees as the threat of castration, is especially strong and he appears to the adult Nathanael on occasion as an Italian eyeglass and spyglass salesman. Regarding the assault on eyes, Coppelius, in a deleted scene, attacks Nathanael's six-year-old sister, described as the exact image of his mother, as she plays with her dolls in the street. Nathanael narrates:

Suddenly the hateful Coppelius stood before us... Hoho hoho little beast, he laughed spitefully, but he appeared to be not without dread of my small person. But suddenly, before I could do anything, he grabbed my little sister... (Hoffmann 972) 
He touches her eyes, Nathanael and Coppelius struggle, neighbors come to the rescue and Coppelius flees, but the sister's eyes begin to hurt, she develops sores, and in three weeks, she is blind. Three weeks later she dies.

Contamination, blindness, death. Coppelius appears to have taken her eyes and extinguished her life with them. Hoffmann likely deleted this scene to keep the figure of Coppelius, the enemy of children, somewhat ambiguous and possibly a figment of Nathanael's active imagination. ${ }^{5}$

The core event of Der Sandmann is a scene that occurs when Nathanael is ten years old and which is recalled, repeated, or re-enacted throughout the tale with its peculiarly hermetic imagery of eyes, fire, and the non-humanity of an apparent human--the last of these being the source of interest for Freud and Jentsch in their investigations of the uncanny. The occasion is Nathanael's traumatic encounter with his father and Coppelius during what is apparently an alchemical experiment. It has the character of a primal scene with the father's altered appearance (ugly, repulsive, demonic) and the witness's horror at the proceedings. Nathanael emerges from his hiding place behind a curtain and is discovered by the alchemists as they tend the fire. Nathanael, in his terror, sees human faces without eyes in the fire and Coppelius is calling for eyes just before he discovers the petrified child:

'little beast!--little beast!' he bleated gnashing his teeth. [He] grabbed me and threw me onto the oven, so that the flame began to singe my hair. 'Now we have eyes, eyes, a nice pair of child's eyes.' (Hoffmann 17) ${ }^{6}$ The father intercedes and saves his son's eyes, but Coppelius insists on observing the mechanism of the hands and feet and it is this moment when Nathanael is demonstratively handled not as a human but as some sort of humanoid building project:

and then he grabbed me violently so that my joints cracked and he unscrewed my hands and feet and put them here and there and then back again. (Hoffmann 17-18) ${ }^{7}$

Having switched Nathanael's feet and hands and tested the new configuration, Coppelius announces that they are best in their original position, acknowledging 
that the "old man" or God knew what he was doing; Nathanael, who has been both beast and doll in this scenario, faints and awakens to the warm attentions of his mother.

The assumption is that Nathanael hallucinated this scene in which his hands and feet were switched, but the treatment of the child is entirely consistent with Coppelius's apparent occupation (if he is indeed Coppola), that of building automata, the clockwork creatures that had already reached a very advanced stage of development in Hoffmann's time. ${ }^{8}$ The creepy lawyer works with fire and eyes and appears much later as the co-creator of Olimpia, an automaton who speaks, sings, dances, and passes for human - albeit for an odd and machinelike human.

In every recurrence of the basic trauma scene we have references to fire, eyes, and a wooden doll or automaton - reflecting the child's horror of being treated as a doll and not as a human. Nathanael has a brief flashback when Coppola visits with eyeglasses; he writes morbid poems that feature someone stealing his or his fiancée Clara's eyes and he suffers his final fit when he and Clara climb a tower for a good view of the city. Coppelius of the gray bushy eyebrows lurks below and Clara points him out as a small gray bush moving toward them. Nathanael views Coppelius once again through the spyglass Coppola had sold him and immediately loses his sanity, trying to murder Clara and raving about a ring of fire, a wooden doll, and eyes. In some deleted dialogue, Coppelius calls out to him: "Ey, ey, little beast--do you want to learn how to make eyes - throw me your wooden doll" (Hoffmann 977). ${ }^{9}$ Nathanael had been trying to throw Clara down before Coppelius spoke but Lothar, her brother, had rushed up the stairs and saved her. In response to Coppelius' call to the little beast to throw down the doll, Nathanael himself jumps and shatters on the pavement. The childhood bogeyman has returned to claim the child.

If we include the deleted lines, the last thing the abused child hears is a reference to himself as beast and doll, the two available alternatives to humanity in this tale. One can argue that he is still the child suggested by those terms. He has failed to mature, to leave his nursery and to relinquish the Sandman of the 
nurse's tale. And it is this Sandman, the Coppelius who hates children, who comes to kill him. His punishment proceeds from this crime of omission: he has failed to marry, to overcome his childhood fears, and to exit the stage of prehumanity that appears variously as that of animals or of wooden dolls. Nathanael is a Pinocchio who does not become a real boy, a human. Like Collodi's figure in the original serialized novel, who was hanged for his many crimes, especially lying, Nathanael, who claims veracity for fantastic tales, is executed by the bad father he, a wooden doll, could not overcome. No Blue Fairy intervenes to assist in his humanization. She defers to the Sandman who intends Nathanael's extermination.

For Hoffmann's tale, eyes are the difference between the human and the non-human - they represent or embody the soul or the essence of humanity and Nathanael succumbs to the fear of losing his eyes, of having his essence stolen in order to animate the villain's creations. Nathanael does not definitively cross the line separating the human and the non-human, and Olimpia, who (according to Spalanzani) has his eyes, also fails to fully pass as human. She makes it through a few social gatherings without detection but she is received by all but Nathanael as oddly mechanical. Spalanzani, her co-creator, derives his name from Lazzaro Spalanzani (1729-99), a scientist famous for his work on the artificial insemination of animals (Hoffmann 973). Olimpia, the artificial human, whom the enchanted Nathanael fails to recognize as non-human, tends to confirm his status as non-human. They are in a very real sense twins, creatures of Coppelius, united by a shared set of eyes that neither retains.

These are the consequences of Nathanael's sins of omission, his failure to grow up and accept the opportunities for adult life offered by his reasonable and domesticating fiancée, Clara. He remains in the world of nursery horrors. The tale closes with a report of Clara having married a "friendly man," with whom she sits "hand in hand before the door of a lovely country house," in front of which two happy boys play. The narrator continues:

One can assume from this that Clara did find the peaceful domestic happiness that fitted her cheerful and life-affirming temperament and that 
the internally tormented Nathanael would never have been able to provide her. (Hoffmann 49) ${ }^{10}$

Though the passage hints at the dullness of such an existence, it Clara-fies for the reader the bourgeois norms that prevail in the adult world, that Nathanael omitted to join. By contrast, in Der Struwwelpeter, it is the crimes of commission rather than omission that bring severe, but purportedly merited, retribution.

\section{Der Struwwelpeter}

In 1844, Dr. Heinrich Hoffmann of Frankfurt am Main went shopping for a picture book to give his three-year-old son for Christmas (Herzog/Siefert 17). ${ }^{11}$ As the oft-told story goes, he was unable to find anything suitable, so he bought a blank book and filled it with his own drawings and verses and, from this modest and heimlich beginning, issued what may be the most famous children's book ever produced, Der Struwwelpeter (1845). The illustrated volume follows the misadventures of several children: Peter, a slovenly child who attains a disgusting appearance, suggesting a disgusting essential being; Friedrich, a bully who abuses his dog and is bitten; Paulinchen who plays with matches and goes up in flames; a disobedient thumbsucker named Konrad who has both thumbs chopped off by a demonic tailor with giant shears; Kaspar who starves to death for not eating his soup, and various other accounts of childhood transgressions met with severe consequences. The book can be likened to a zoo full of children instead of animals, who are exhibited for their vices. They are trapped in its pages, where they make their poor choices and teach by negative example.

Though the title, translated by Mark Twain as Slovenly Peter and elsewhere as Shock-headed Peter, indicates poor hygiene and sloth, Hoffmann (1809-94) was himself no slouch, but rather a multi-faceted, highly accomplished and effective individual. In addition to being a successful physician, he also left a rather large political footprint. During the turmoil of 1848 in Frankfurt, Hoffmann, who campaigned for the liberal goal of a constitutional monarchy, was a member of the Vorparlament, then was elected to the first parliament, and to the constitutional convention. He was a member of a number of social and learned 
societies (Gesellschaft der Tutti-Frutti, Die Bäder des Ganges) and was also a freemason for a time- -though he left the masonic brotherhood because they refused to admit Jews. One of his medical specializations was psychiatry and he had a hand in establishing a sub-specialization in child psychiatry. As physician to the mentally ill in general, Hoffmann campaigned for actual treatment rather than storage and arranged for open house days in the mental hospital where he worked, as a means of normalizing such disorders (as opposed to concealing those who suffer from them). Though a prominent person in Frankfurt at the time, he is far less recognizable to posterity than E.T.A. Hoffmann.

Struwwelpeter, which grew out of the funny pictures Heinrich Hoffmann drew to calm his frightened child patients, is itself regarded as a treatment, a dose of medicine and shock therapy meant to socialize and humanize children, by encouraging them to distance themselves from the savage figures in the book, especially that of the iconic title figure, "disgusting [garst'ger] Struwwelpeter." The latter's deplorable condition can be read as a reflection of a slovenliness within, a failure to make the moral choice of duty over inclination, Pflicht over Neigung. ${ }^{12}$ Peter, of the lion's mane and tiger claws, was certainly aware of his duty to groom himself or allow himself to be groomed--the verses suggest active resistance to grooming rather than omission--but he chose to follow his inclination and his subsequent appearance is his punishment, an image from which one can read his inner stagnation or his budding moral turpitude. Like a figure in the stocks with his crime proclaimed for passers-by, Peter stands on a pedestal on which is inscribed the verse decrying his transgression.

Just look at him! there he stands,

With his nasty hair and hands.

See! his nails are never cut;

They are grimed as black as soot;

And the sloven, I declare,

Never once has combed his hair;

Anything to me is sweeter

Than to see Shock-headed Peter. ${ }^{13}$ 
The rhyming English version does not quite capture the omission-commission distinction of the German, but it conveys the result.

This is the only single-image segment in the book and the only one where we are confronted with the stark results of bad behavior without a full account of the sorry events leading up to punishment. Except for the inky boys, it is also the only segment where appearance is its own punishment - they were dipped into an inkpot and made even blacker than the black African man they were mocking. With this Hoffmann indicates that one should be tolerant of difference, but he does not argue for the parity of the different. The whole tale of Struwwelpeter is a single page, a single image, apparently meant to shock and reform or, more felicitously, to pre-empt inattention to hygiene.

Struwwelpeter was not the original title. It was the rather lengthy and pragmatic "Lustige Geschichten und drollige Bilder mit 15 schön kolorierten Tafeln für Kinder von 3-6 Jahren" [Funny Stories and Humorous Pictures with 15 Pretty Colored Illustrations for Children from 3-6 years]. Struwwelpeter became the title with the third edition and largely because readers, namely children, were calling it that, having picked the lone little boy, pars pro toto, to represent the book. And it was not until the fifth edition that the figure occupied the cover (Klein 18-19). ${ }^{14}$ But the stark iconic image, raised up to title and lead-story status, represents the triumph of image over text in a book that presents both. Peter's "funny story" is barely there-a few lines written on his pedestal. It is the sight of him, a "humorous picture" that conveys a message that is much more textdependent in the other, more narrative, vignettes. Hoffmann maintained: "Children learn with their eyes and they only understand that which they can see"--eyes being the ticket to learning in this case and, through learning, to socialization and humanity (Herzog/Siefert 14). Hoffmann's early audience may have proved him correct by re-naming the book after the stark single image. Children between 3 and 6 are both pre-human and largely pre-literate--though the book also appealed to older, more literate children. Hoffmann was also a pretty good writer of silly verse and the subsequent lessons, given in greater lexical detail, have also made a serious impact. 
To summarize the sequence of short illustrated tales, we see and read about children who either ignore the obvious tenets of good behavior on their own or children who are specifically warned not to do something, either by parents or by agents of parents. They ignore the warning or they ignore the norm, failing to advance toward bourgeois civilization, and they are punished. However, this punishment never proceeds from the parents, the norm-enforcing authorities, though it occasionally appears to come from outside agents. I say "appears" because I believe that the lesson to be learned is that the punishment is a direct unmediated consequence of the behavior - that is, the children are the immediate agents of their own punishment. If you play with matches, you set yourself on fire; if you mistreat your dog, you cause him to bite you; if you suck your thumbs, you conjure a figure with giant shears who cuts them off; if you don't sit still, you fall off your chair and so forth. These are the lessons of civilization - one is responsible for one's proper behavior and one must accept the consequences of misbehavior.

In the US state of Texas (this is only an apparent digression), the death certificates of executed prisoners listed "homicide" as the cause of death, where usually one would expect a medical cause, like "heart failure." This was the practice until 2005, when Governor Rick Perry signed House Bill 93 changing that to "judicially ordered execution." He did so because many understood the "homicide" etiology as the state's admission that it had killed or even murdered the inmate, when this was not the state's message at all. The homicide referred to was that committed by the executed man or woman, an act that triggered the process ending in his or her death - just as little Konrad's rebellious decision to suck his thumb summoned the tailor with his shears. In this case, the citizen acting through the state actually caused his or her own death, just as Konrad caused the amputation of his thumbs by transgressing domestic law. It is even more incestuous with Peter, whose punishment not only fits his crime, but is his crime. The physical alteration that constitutes his transgression is the penalty for that transgression. In Struwwelpeter, as in Texas, the transgressors are themselves the agents of their own punishment - or they are themselves their 
punishment--making a single closed circuit of offense and the response that is its counterweight. The state of Texas merely did its duty - and unlike the children in Hoffmann's book, it could not have done otherwise. Kant's dictum, "If he has murdered, then he must die" [Hat er aber gemordet, so muss er sterben], from the Metaphysische Anfangsgründe der Rechtslehre (Kant 452) is taken very seriously in some death penalty states, such that punishment is the inevitable result of crime or, more properly, crime is the cause of punishment. Penal laws or parents' warnings inform about the consequences for transgression and disregard for these warnings directly effects these consequences. The mediation of state or tailor with shears is merely apparent because the perpetrator punishes himself (or herself - there is one misbehaving girl in the book and the occasional woman executed in Texas). ${ }^{15}$

This is the repressive argument of Struwwelpeter, the lesson of bourgeois civilization and the ticket to humanity. The book can be read as an authoritarian catechism of black pedagogy pitched at young children, that they might learn compliance through fear and strict application of the rules. ${ }^{16}$ Parents can warn you but no one can save you once you have transgressed--thus better not to transgress. To internalize and apply this lesson is to achieve socialization and to create the perception that one is human and no longer subject to legitimate abuse by dogs, tailors, or natural forces. Yet Struwwelpeter has a dual aspect, and reaches beyond the mere education to social docility. There is another distinction between human and animal in play.

The consequences for personal freedom, self-expression, and creative choice here would seem dire: having observed these unfortunate children, we could conclude that we are morally confined within the daunting walls of a strictly circumscribed bourgeois society - and this has been the conclusion of many professional adult readers who have considered Hoffmann's message. But there is another side to this book that self-identifies as "funny" and "humorous." Not only is the book so extreme in its lessons as to invite a jocular response, so exaggerated that one can barely take it seriously - though many claim to have done so in childhood - but it is in an important sense about the exercise of the 
freedom it appears to contest. Though these children are punished as nonhumans or failed humans, they exhibit one exalted feature of humanity. We witness the expression of volitional freedom in almost every vignette - no one is coerced to behave or not to behave and parents leave small children alone to determine the course of their actions. Peter, Friedrich, Paulinchen, the Inky Boys, Konrad, Kaspar, Hans, and Robert are eerily alone without obvious adult supervision. Much like the children in Charles Schultz's Peanuts, they move in a world where adults are not visible and children must make their own decisions. It is interesting that Schultz's Lucy, like Hoffmann, practices psychiatry - the doctor is IN these stories but so is the humorist and the politician who stood between the extremes of monarchy and republic. Each Struwwelpeter child makes a free decision to do that which he has been told not to do, illustrating that freedom prevails even under attempts to enforce norms--its exercise may be misguided but it prevails. Without the prior restraint often applied in childhood, there is resistance to authority and to norms and in the 1840s in Frankfurt some resistance was positively charged.

So the authoritarian or repressive argument is only part of the essence of the book, whose straightforward simplicity and outrageous clarity of retribution tend to undermine any attempt to take it seriously. If education inevitably involves coercion, this is a relatively mild application. The learning outcomes of this black pedagogy transcend the obvious (if he has murdered, then he must die; obey or die) and re-focus on the issue of free will or free choice.

Against those who see Struwwelpeter as teaching only compliance and submission to normative discourses and against those who see it specifically as having prepared Germans to submit to the Third Reich by cultivating an authoritarian personality, ${ }^{17}$ I want to advance the other side of the coin, namely the revolutionary argument. These children transgress! They bust norms and question authority. Peter von Matt reads most emphatically against the normative grain in his afterword to the German Reclam edition, giving several examples of possible revolutionary intent. First of all, he sees in Struwwelpeter's image the facial expression of the suffering Christ, of an ecce homo portrait (von Matt 67). 
Perhaps there is salvation in Peter's resistance to hygiene? More to the point, von Matt turns to the appearance of "nasty Frederick," standing on a wall and raising a chair in his hand as he rages against all forms of proper behavior and sees a descendent of Delacroix's La Liberte guidant le peuple in the image. (von Matt 72) Could Frederick be leading us away from compliance? Von Matt also notes that Hoffmann's publisher, Löwenthal, published a number of Vormärz authors, as well as Marx \& Engels (von Matt 71). As Beate Zekorn von Bebenburg writes, the foregrounded moral is undermined by subversive messages (Zekorn von Bebenburg 56).$^{18}$ There is revolution and anarchy in the children's decisions to disobey or to ignore norms in favor of self-expression. These children refuse to join humanity and choose to persist as misfits. It is ironic that the means by which they resist bourgeoisification (here seen as humanization) is the exercise of free will, generally considered a distinguishing mark of humanity.

Among its more affirmative applications, Struwwelpeter has also been enlisted as protection against evil, specifically the evil represented by a child's nightmare world, that realm of fear that Nathanael conjured and that small children experience and adults dismiss. In a recent issue of Hellblazer comics, entitled "Reasons to be Cheerful," Mike Carey deploys Hoffmann's Struwwelpeter figure as a kind of super-hero who appears on command to defend the adult heroine from the terrible creatures of her childhood dreams who now threaten her with actual and serious physical damage. To an extent, this is an enactment of Bruno Bettelheim's contention that children need monsters to embody and focus their fears, so that they can be overcome (Bettelheim 120). Hellblazer is the vehicle for John Constantine, an exorcist and psychic, well known to readers of DC and Vertigo comics. Constantine agitated years ago in Swamp Thing comics as an interlocutor for the Swamp Thing and he now stars in Hellblazer as an itinerant antagonist for devils and demons. In this particular story, Constantine comes to the aid of a young woman named Angie Spatchcock during a dreamdemon attack. Joining her in her dream and seeing the demons closing in, he desperately asks her to try to recall how she dealt with the nocturnal threats as a 
child. She replies: "Peter! Shock-headed Peter! He was the worst - the scariest so I made him be on my side" (Carey). Angie then calls Peter, who appears, swells to enormous size, and heroically kills all the demons. "Nicely done," intones Constantine and Peter replies by repeating the opening lines of the book in German: "Wenn die Kinder artig sind, kommt zu ihnen das Christkind" [when children are well-behaved the Christ child comes to them \{with Christmas presents\}] as if Carey were mocking the premises of the children's book, by invoking its conventional reward system (Carey). Here we are in an adult world of terror and it was Peter, not Christ (ecce homo) who was Angie's salvation. Hellblazer's Peter is a terror so great (we see child Angie reading it in the beginning) that it reverts into its opposite, a benevolent protector against lesser horrors, and apparently all horrors are lesser. Angie has seized the icon of prehuman punishment and used him to her advantage. Unlike Nathanael, who taps his horrors in order to repeat and relive them, Angie fights her way through the tokens of pre-humanity to full-fledged human status.

Thus Struwwelpeter has a number of conflicting aspects. It is severe, terrifying, lustig, drollig, and liberating. Much like Freud's uncanny (usually applied to the other Hoffmann's tale) it apparently frightens and soothes, threatens and protects. Retreating from Hellblazer and its super-Struwwelpeter, what I believe Struwwelpeter actually does is to stage a dialectic of compliance and noncompliance, repression and revolution, culminating in a dynamic that lends it its power and its durability. Obedience to parents and a normative social superstructure is nominally recommended and its antithesis is presented for consideration. "Consequences," as we call punishment nowadays, play a central role and they are the obstacle to freedom - unless one can accept and overcome them. Peter accepts his consequences as anyone can plainly see; Kaspar accepts the consequences of not eating soup at the cost of his life; Friedrich and the inky boys persevere as punished subjects-whether they are reformed by the punishment is not clear. Their further activities are not important-they exist in the moment of their transgressions for the child spectator/auditor to perceive and process. 
Struwwelpeter repeatedly stages a clear moral choice as the conflict between compliance or non-compliance - for individuals who cannot or do not self-overcome, namely children. Beyond this there is humor - the dialectic of Struwwelpeter is an extremely serious social message juxtaposed to a very humorous presentation that refuses to excuse the offender. The two merge in a frankly compelling Aufhebung or sublation. The child, thus uplifted, medicated, or inoculated, has experienced a didacticism so extreme that it incorporates its opposite, namely a health respect for those free-thinking radicals who do not cut their nails, eat their soup, or follow parental orders.

Beyond this, and in conclusion, I believe we can, in nineteenth-century Germany and elsewhere in other ages, identify a certain disregard for the suffering of wayward young children. The broadness and duration of the Roman Catholic Church's sex abuse scandal speaks volumes about the assumed nonhumanity or partial humanity of young children. When in the course of human development, a will emerges that can express itself in noncompliance and which is not yet matched by full physical and intellectual maturity, we may witness the abuse of children. For the restricted realm I have addressed in this essay, that abuse is based on their exclusion from bourgeois humanity.

\footnotetext{
${ }^{1}$ The Heinrich Hoffmann-Struwwelpeter Museum in Frankfurt has an extensive collection of Struwwelpeter parodies on display from its permanent collection. Freud also chimed in on Struwwelpeter, identifying fear of castration as the underlying message of at least one of the tales, that of Konrad the thumbsucker. (Freud, Vorlesungen 428).

${ }^{2}$ Interestingly, the German band Rammstein gives voice to Paulinchen in their "Hilf mir," as they revise Hoffmann's verses to let her speak of her attraction to fire and the pain it causes. From Rosenrot . sound and lyrics at http://www.youtube.com/watch?v=TpqXJ-zzQQs I am grateful to Jaime Roots for this reference.

${ }^{3}$ Das ist ein böser Mann, der kommt zu den Kindern, wenn sie nicht zu Bett gehen wollen und wirft innen Händevoll Sand in die Augen, dass sie blutig zum Kopf herausspringen, die wirft er dann in den Sack und trägt sie in den Halbmond zur Atzung für seine Kinderchen; die sitzen dort im Nest und haben
} 
krumme Schnäbel, wie die Eulen, damit picken sie der unartigen Menschenkindlein Augen auf. Translations are mine unless otherwise noted. ${ }^{4}$ Da stand mit einem Mahl der verhasste Coppelius vor uns.... Hoho hoho klein $<e>$ Bestie-lachte er hämisch, aber er schien nicht ohne Scheu vor meiner kleinen Person. Doch schnell, ehe ich mir's versah, ergriff er $m<e$ eine> kleine Schwester.

${ }^{5}$ See Hartmut Steinecke and Gerhard Allroggen's commentary in the Deutsche Klassiker edition (Hoffmann 973).

6 "kleine Bestie!-kleine Bestie" meckerte er zähnfletschend!-riss mich auf und warf mich auf den Herd, dass die Flamme mein Haar zu sengen begann: "Nun haben wir Augen-Augen-ein schön Paar Kinderaugen."

${ }^{7}$ Und damit fasste er mich gewaltig, dass die Gelenke knackten, und schrob mir die Hände ab und die Füsse und setzte sie bald hier, bald dort wieder ein.

${ }^{8} \mathrm{~A}$ single but prominent example are the creations of Swiss watchmaker Pierre Jacquet-Droz (1721-90). His masterpiece, The Writer, consists of over 6000 parts, and can be programmed through input tabs to write almost any text. This automaton is still on display in the Musée d'Art et d'Histoire in Neuchatel, where it is regularly operated. The museum also has his Draughtsman and Musician, both of which are still in operation, the point being that creatures such as Olimpia seemed to be a distinct possibility in Hoffmann's day.

${ }^{9}$ Ey, Ey--Kleine Bestie-willst Augen machen lernen-wirf mir dein Holzpüpchen zu....

${ }^{10}$ Nach mehreren Jahren will man in einer entfernten Gegend Clara gesehen haben, wie sie mit einem freundlichen Mann, Hand in Hand, vor der Tür eines schönen Landhauses sass und vor ihr zwei muntre Knaben spielten. Es wäre daraus zu schliessen, dass Clara das ruhige häusliche Glück noch fand, das ihrem heiteren lebenslustigen Sinn zusagte und das ihr der im Innern zerrissene Nathanael niemals hätte gewähren können.

${ }^{11}$ The story derives from Hoffmann's letter to the Gartenlaube of 3 November 1892, responding to their request for an account of the origin of the book (Herzog/Siefert 11-17).

${ }^{12}$ Reimar Klein makes the point about duty and inclination and Kant's moral philosophy (Klein 14ff.).

${ }^{13}$ Project Gutenberg, translator unidentified. Mark Twain's translation preserves more of the agency of the "sloven": See this frowsy "cratur" - Pah! It's Struwwelpeter! On his fingers rusty, On his tow-head musty, Scissors seldom come; Let his talons grow a year, - Hardly ever combs his hair, - Do any loathe him? Some! They hail him "Modern Satyre - Disgusting Struwwelpeter." Hoffmann's original reads: "Sieh einmal, hier steht er/Pfui! der Struwwelpeter!/An den Händen beiden/Liess er sich nicht schneiden/Seine Nägel fast ein Jahr;/Kämmen liess er nicht sein Haar./Pfui! ruft ein Jeder:/Garst'ger Struwwelpeter." (Hoffmann/von Matt 8).

${ }^{14}$ Klein's extended essay on the whole book and its parts, along with von Matt's Nachwort, is one of the best pieces available on Struwwelpeter. 
${ }^{15}$ An application of this principle that is somewhat closer to (academic) home is the doctrine that students who cheat are only cheating themselves because they lose out on the experience of learning.

${ }^{16}$ Klein quotes without citation a common view of it as "pädagogischen Katechismus des Kleinbürgertums in der zweiten Hälfte des 19. Jahhunderts" (7). ${ }^{17}$ This is the argument of Jack Zipes in an older piece, (Zipes 162-179). Thomas Freeman responds that Struwwelpeter was more a reflection of an authoritarian personality than a cause (Freeman 813)

18 "Die vordergründige Moral der Geschichten wird von subversiven Botschaften konterkariert."

\section{Works Cited}

Bettelheim, Bruno. The Uses of Enchantment: The Meaning and Importance of Fairy Tales. New York: Knopf, 1976. Print.

Carey, Mike, Manco Leonardo. "Reasons to Be Cheerful: Part 3." John Constantine Hellblazer 204, Vertigo Comics. USA: Capcom, 2005. Unpaginated. Print.

Freeman, Thomas. "Heinrich Hoffmann's Struwwelpeter: An Inquiry into the Effects of Violence in Children's Literature." Journal of Popular Culture 4 (1977): 808-820. Print.

Freud, Sigmund. Vorlesungen zur Einführung in die Psychoanalyse 23 (1916-17).

Paderborn: Outlook Verlagsgesellschaft, 2012. Print.

. "Das Unheimliche." Imago: Zeitschrift für Anwendung der Psychoanalyse auf die Geisteswissenschaften 5 (1919): 197-324. Print.

Herzog, G.H., Siefert, Helmut, ed. Struwwelpeter-Hoffmann: Texte, Bilder, Dokumentation, Katalog. Frankfurt am Main: Verlag Heinrich Hoffmann Museum, 1978. Print.

Hoffmann, Ernst Theodor Amadeus. Sämtliche Werke in sechs Bänden III. Ed. Wulf Segebrecht et al. Frankfurt am Main: Deutsche Klassiker Verlag, 1985. Print. 
Hoffmann, Heinrich. Letter to the Gartenlaube 3 November 1892. Reprinted in Struwwelpeter-Hoffmann. Ed. G.H. Herzog, Helmut Siefert. Frankfurt am Main: Verlag Heinrich Hoffmann Museum, 1978. 11-17. Print. . Der Struwwelpeter oder lustige Geschichten und drollige Bilder. Nach der Druckfassing von 1859 unter Berücksichtigung der Handschriften. Ed. Peter von Matt. Stuttgart: Reclam, 2009. Print.

Kant, Immanuel. "Von Straf- und Begnadigungsrecht." Metaphysische Anfangsgründe der Rechtslehre, Werke 4. Darmstadt: Wissenschaftliche Buchgesellschaft, 1966. Print.

Klein, Reimar. 'Sieh einmal, hier steht er' Struwwelpeters beschädigte Kinderwelt. Frankfurt am Main: Insel, 2005. Print.

Matt, Peter von. "Erfolg als Rätsel." Nachwort in Heinrich Hoffmann Der Struwwelpeter, 2009. 57-76. Print.

Zekorn-von Bebenburg, Beate. "Struwwelpeter wird Revolutionär." Herzog/Siefert, 54-70.

Zipes, Jack. "Down with Heidi, Down with Struwwelpeter, Three Cheers for the Revolution!" Children's Literature 5 (1976): 162-79. 